Click www.researchjournal.co.in/online/subdetail.html to purchase.

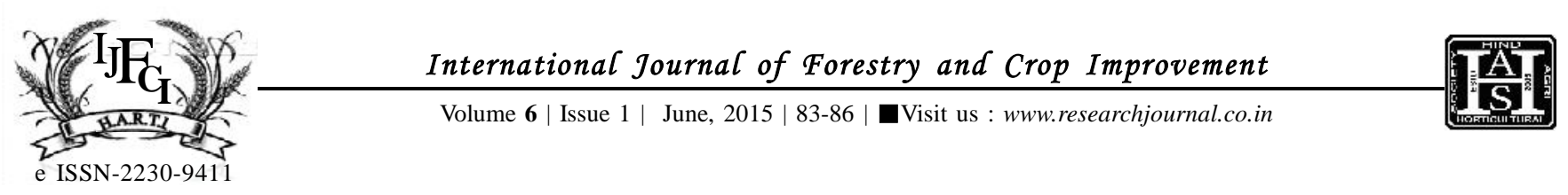

\title{
Seed priming - An effective method for crop production
}

\author{
ApUrbaDas, Rituraj Boruah, SANKu Moni Sharma and Joyarani Pegu
}

KEY WORDS : Seed priming, Crop production

How TO CITE THIS ARTICLE : Das, Apurba, Boruah, Rituraj, Sharma, Sanku Moni and Pegu, Joyarani (2015). Seed priming - An effective method for crop production. Internat. J. Forestry \& Crop Improv., 6 (1) : 83-86.

Article Chronical : Received : 01.09.2014; Accepted : 28.05.2015

\section{INTRODUCTION}

Seed may be considered as the most important and vital factor which is structurally a fertilized matured ovule consisting of an embryonic plant along with a store of food in the form of endosperm and a protective seed coat. Seed quality has been taken as an essential and important factor in the improvement of agriculture from the time immemorial. The agrarian societies are very much aware about the fact and the evidences are found in the old Vedic literatures. The old scripture, Manu Smriti says "Subeejam Sukshetre Jayate Sampadyathe" i.e. good seed in good soil yields abundantly. The Rigveda, 2000 BC indicate the importance accorded to seed and the mother earth. Fifth century "Kautilya Artha Shasthra" and "Surapalas Vrikshayurveda" mentioned about the importance of seed and its protection from the harmful

\section{MEMBERS OF RESEARCH FORUM}

Address of the Correspondence : SANKU MONI SHARMA, Department of Extension Education, College of Agriculture, Assam Agricultural University, JORHAT (ASSAM) INDIA

Address of the Coopted Authors : APURBA DAS, Department of Microbiology, College of Sericulture, TITABAR (ASSAM) INDIA

RITURAJ BORUAH, Department of Extension Education, College of Horticulture, NALBARI (ASSAM) INDIA

JOYAR $\overline{\text { ANI PEG }}-\overline{\mathrm{U}, \text { Department of Plant Pathology, College of Horticulture, NALBARI }}-\overline{-}$ (ASSAM) INDIA factors in the initial stage by seed dressing with cow dung, milk, honey and vidanga. In recent era, the need for good quality seed was identified at the beginning of $20^{\text {th }}$ century when Royal commission of Agriculture (1928) recommended spread of improved varieties and seed distribution.

\section{Importance of quality seed :}

- Seed is an essential and vital input in crop production.

- It is the cheapest and key input in crop production for agricultural progress.

- Crop production and productivity largely depends on the seed materials used for sowing.

- The performance of the other inputs in crop production depends on seed material used.

- In comparison to the other agricultural inputs like fertilizers, insecticides, fungicides, bactericides etc., the cost of seed is relatively less. This emphasizes the need for increasing the area under quality seed production.

- It has been estimated that good quality seeds of improved varieties can enhance the agricultural productivity by $20-25$ per cent.

- The advent of modern plant breeding methods 